\title{
PEMIKIRAN WAHBAH AL-ZUHAILY TENTANG AHKAM AL-USRAH
}

\author{
Faridatus Syuhadak dan Badrun \\ Fakultas Syariah UIN Maulana Malik Ibrahim Malang \\ Email: faridasyuhada@yahoo.com
}

\begin{abstract}
Abstrak
This research is a normative judicial, with historical-analytic approach. Method of collecting data uses literature study, while the analysis of the data uses content analysis. The results showed that in applying ijtihad, Wahbah al-Zuhaily first review the texts contained in the Qur'an by using an approach related disciplines such as linguistics who heed the words mujmal, musytarak, 'amm or Khass, haqiqah or majaz, haqiqah or 'urf, muthlaq or muqayyad etc, then the Prophet hadith; qauliyah, amaliyah, and taqririyah. After that he used qiyas and maslahah consideration for the realities faced by using the general rules as istihsan, maslahah mursalah, urf, sadd adh-Dzari'ah and others. Wahbah al-Zuhaily begins discussion of family law with a preliminary discussion of marriage; shari'ah law marriage, marriage sermon, proposed marriage proposal of others, and see the woman who had been groom before marriage. Wahbah al-Zuhaily also explained that the marriage law is not always the Sunnah, but can change mandatory, permissible, forbidden even makruh, depending on the context.

Penelitian ini merupakan penelitian yuridis normative, dengan pendekatan historisanalitis. Metode pengumpulan data menggunakan studi kepustakaan, sedangkan analisis data menggunakan content analysis (analisis isi). Hasil penelitian menunjukkan bahwa dalam melakukan ijtihad, Wahbah Al-Zuhaily terlebih dahulu melakukan kajian terhadap nash-nash yang terdapat dalam al-qur'an dengan menggunakan pendekatan disiplin ilmu yang terkait seperti ilmu bahasa yang memperhatikan kata-kata mujmal, musytarak, 'amm atau khashsh, haqiqah atau majaz, haqiqah atau 'urf, muthlaq atau muqayyad dll, kemudian hadits Rasul baik yang Qauliyah, amaliyah, maupun taqririyah. Setelah itu menggunakan qiyas serta pertimbangan maslahah bagi realitas yang dihadapi dengan menggunakan kaidah-kaidah umum seperti istihsan, maslahah mursalah, urf, sadd adz-Dzari'ah dan lain-lain. Wahbah Al-Zuhaily memulai pembahasan hukum keluarga dengan pembahasan tentang pendahuluan pernikahan; hukum pernikahan secara syari'at, khutbah pernikahan, meminang pinangan orang lain, dan melihat perempuan yang telah dipinang sebelum dinikahi. Wahbah Al-Zuhaily juga menjelaskan bahwa hukum pernikahan tidak selalu sunnah, tapi bisa berubah wajib, mubah, makruh bahkan haram, tergantung konteksnya.
\end{abstract}

Kata kunci: Pemikiran, Wahbah Al-Zuhaily, Al-Ahkam Al-Usrah

Wahbah al-zuhayli merupakan salah satu tokoh yang cukup signifikan dalam jajaran tokoh-tokoh ulama pakar hukum Islam. Nama lengkap Wahbah al Zuhaili adalah Wahbah bin Musthafa al Zuhaili.Wahbah lahir pada tahun 1932 M di Damaskus, ibukota Siria. Di era Wahbahal-Zuhayli, terutama pada paruh kedua abad ke 20, Negara-negara mayoritas 
berpendudukan muslim ditandai dengan kondisi serupa, yaitu ada kecenderungan mayoritas penduduknya kepada madhab fiqh tertentu (dalam hal ini Siria mengikuti madhab Hanafi ). Walau begitu keragaman parsial tetap dijamin kemerdekaannya dengan memberikan tempat pada madhab figh lain, utamanya kategori madhab Sunni. Disamping itu periode kehidupan Wahbah juga diwarnai oleh keharusan beradaptasi dengan teori (hukum) konvesional dalam praktek muamalah tantangan atau problema kehidupan terasa membenahi umat Islam akibat dari modernisasi kemajuan teknologi yang mendorong manusai bersikap praktamis. Dan hal itu diperparah dengan tanpa diimbangi oleh ulama Negara setempat untuk cepat tanggap dalam merespons kenyataan yang ada. Hal semacam inilah yang tampaknya mendorong Wahbah untuk menulis fiqh ensiklopedia yang berjudul al Figh al Islam wa Aldilltuhu. ${ }^{1}$

Fiqh Islam atau biasa disebut dengan hukum Islam begerak di wilayah praktis, yakni berhubungan dengan perilaku manusia yang metode perumusannya dengan memanfaatkan daya penalaran atas dalil-dalil shar'i. obyek kepraktisan fiqh memposisikan ketersediaan wacana doktrinnya harus berpadu dengan perkembangan zaman dan setidaknya hal itu telah membangkitkan kembali pemikiran dan konsepsional fiqh. Dalam hal ini dibutuhkan strategi pengembangan fiqh Islam yang sekiranya bisa melahirkan solusi pemecahan problema yang di anggap ummat Islam, khususnya di bidang hukum. Banyak intelektual-intelektual muslim dan pemerhati (ahli) hukum Islam yang mencoba untuk menata strategi perumusan kembali konsepsional fiqh yang nantinya diharapkan bias menjawab tantangan zaman yang dihadapi ummat. Diantara para intelektual muslim sebagaimana dikatakan diatas adalah Wahbah Al Zuhaili. Untuk itu peneliti menganggap penting untuk mengkaji sosok dan kiprahnya di dunia hukum Islam.

${ }^{1}$ Wahbah Zuhayli, al-Figh al-Islam wa Adillatuh, juz 1 (Damascus, Dar al-Fikr 2006)

\section{Metode penelitian}

Penelitian ini apabila dilihat dari bentuk sumber datanya yang berupa buku-buku atau karya tulis lainnya maka termasuk dalam penelitian yuridis normative atau penalitian hukum doctrinal. Dalam penelitian hukum jenis ini, hukum di konsepkan sebagai apa yang tertulis dalam peraturan (law in books) atau sebagai kaidah yang merupakan patokan perilaku manusia yang dianggap pantas. ${ }^{2}$ Sedangkan pendekatan yang digunakan dalam penelitian ini adalah pendekatan kualitatif. Menurut Lexy J. Moleong, penelitian kualitatif adalah penelitian yang bermaksud untuk memahami fenomena tentang apa yang dialami oleh subyek penelitian, misalnya perilaku, persepsi, motivasi, tindakan dan lain-lain secara holistic dan dengan cara mendeskripsikannya dalam bentuk kata-kata dan bahasa pada suatu konteks khusus yang alamiah dan dengan memanfaatkan berbagai metode alamiah. ${ }^{3}$ Penelitian dengan pendekatan kualitatif menghasilkan data-data yang bersifat deskriptif ${ }^{4}$ karena penelitian dengan pendekatan tersebut sangat kaya dan sarat dengan deskripsi. ${ }^{5}$ Sementara itu berdasarkan disiplin Ilmu yang dipakai yaitu Tarikh Tasyri', pendekatan yang digunakan dalam penelitian ini adalah historis, analitis dan filosofis karena tema yang di angkat berkisar pada pemikiran ulama'. ${ }^{6}$

Dalam penelitian hukum selalu diawali dengan premis normative, maka datanya diawali datanya diawali dengan data sekunder. Bagi Penelitian Hukum normative yang hanya mengenal data sekunder saja, jenis datanya adalah bahan hukum primer, bahan hukum sekunder dan bahan hukum tersier. ${ }^{7}$

Adapun metode pengumpulan data yang digunakan dalam penelitian ini adalah penelaahan naskah atau studi kepustakaan, yaitu cengan

${ }^{2}$ Amiruddin \&Zainal asikin, Pengantar metode penelitian Hukum, Jakarta raja Grafindo Persada, 2006), h. 118.

${ }^{3}$ Amiruddin, Pengantar Metode.., h. 6

${ }^{4}$ Burhan Ashofa, Metode apenelitian Hukum (Jakarta, Rineka Cipta, 2004), 15

${ }^{5}$ Cik Hasan Bisri, Pilar-pilar penelitian Hukum Islam dan Pranata Sosial, ( Raja Grafindo Persada, 2004) 272.

${ }^{6}$ Cik Hasan Basri, Pilar-pilar..., h.17

${ }^{7}$ Amiruddin, Pengantar Metode.., h. 31 
mengumpulkan data primer yang diambil dari buku-buku secara langsung berbicara tentang permasalahan yang diteliti dan juga dari data-data sekunder yang secara tidak langsung membicarakannya namun relevan untuk di kutip sebagai pembanding. Dan metode analisis data yang di gunakan dalam penelitian ini adalah content analysis (analisis isi). Content analisis menunjuk kepada metode analisis yang integrative dan secara konseptual cenderung diarahkan untuk menemukan, mengidentifikasi, mengolah dan menganalisa dokumen untuk memahami makna, signifikasi dan relevansinya. ${ }^{8}$

\section{Hasil dan Pembahasan}

Dalam kitab fiqih Islam wa Adillatuhu jilid ke-9 tentang pernikahan, secara gamblang Wahbah Al-Zuhaily menerangkan hasil pemikirannya tentang hukum keluarga (al-Ahkam al-usrah), menurutnya hukum pernikahan tidaklah tunggal sebagaimana yang banyak telah dipahami atau terekspos umat selama ini. Hukum pernikahan ternyata tidak selalu sunnah, tapi bisa berubah wajib, mubah, makruh bahkan haram, tergantung konteksnya. Sunnah adalah hukum asalnya, dimana hukum sunnah ini berlaku disaat kondisi stabil yang sekiranya ia tidak khawatir terjerumus ke dalam perzinahan jika tidak menikah, juga tidak akan khawatir akan berbuat zalim atau aniaya terhadap istrinya jika ia menikah.

Sedang wajib-nya, bagi laki-laki dan perempuan yang mampu melaksanakan pernikahan tersebut serta berpotensi akan terjebak dalam perzinahan seandainya ia tidak menikah, dan ia juga mampu memberikan na

istrinya berupa mahar dan nafkah batin serta mampu memenuhi hak-hak pernikahan yang lainnya. Ia juga tidak mampu manjaga dirinya untuk tidak terjerumus ke dalam perbuatan yang hina dengan cara berpuasa, sehingga ia berkewajiban menjaga harga dirinya dengan menikah. Karena menurutnya sesuatu yang

\footnotetext{
${ }^{8}$ Burhan Bungin, "Metodologi Penelitian Kualitatif" Aktualisasi metodologis kearah ragam varian kontemporer, (Jakarta, raja Grafindo Persada, 2007), h. 203
}

menjadi sarana kesempurnaan suatu kewajiban maka hal tersebut hukumnya wajib. Mubah bagi mereka yang mampu secara lahir dan batin dan tidak khawatir akan terjebak zina bila tidak melakukan pernikahan.

Makruh bagi seseorang yang berniat menikahi perempuan, tapi khawatir ia tidak dapat bertanggung jawab secara sosial dan ekonomi, selain itu ia juga khawatir akan melakukan dosa dan marabahaya, tetapi kekhawatiran tersebut belum sampai pada derajat keyakinan akan melakukan dosa jika ia menikah. Sedang hukum nikah yang asalnya sunnah akan menjadi haram, apabila pernikahan tersebut justru dilandasi keinginan balas dendam atau menyakiti, menzalimi dan membahayakan istrinya, selain dari itu juga yakin tidak akan mampu memenuhi kebutuhan pernikahan dan tidak mampu berbuat adil di antara istri-

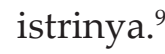

Selanjutnya menurut Wahbah Al-Zuhaily jika terjadi pertentangan antara hal yang mewajibkan seseorang untuk menikah dan yang mengharamkannya, seperti halnya ia akan terjerumus kedalam perzinahan jika ia tidak menikah, tetapi ia juga akan melakukan kezaliman atau menyakiti istrinya jika ia menikah, maka pernikah tersebut tetap hukumnya haram. Karena sesuatu yang yang halal dan haram bercampur maka yang haramlah yang dimenangkan. Ia juga berdalilkan firman Allah surat an-Nuur ayat 33 sebagiaman berikut:

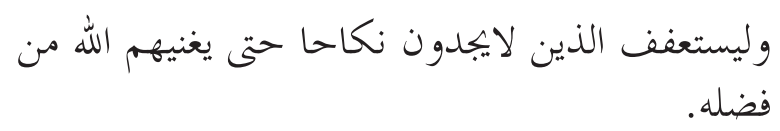

"Dan orang-orang yang tidak mampu kawin hendaklah menjag kesucian dirinya, sehinga Allah memampukan mereka denagn karunia-NYA"

Contoh tersebut menunjukkan, dalam melaksanakan syariat tidak boleh melupakan maqashid syariah-nya. Agama tidak semata soal halal-haram, tapi sarat berbagai pesan moral yang kadang dilupakan. Wahbah juga menerangkan beragam penafsiran tentang sejauh mana kebolehan melihat calon pasangan dalam pinangan, menurutnya melihat

\footnotetext{
${ }^{9}$ Wahbah Al-Zuhaily, Fiqih Islam wa Adillatuhu, (gema insani, jakarta 2010), h. 41
} 
aurat perempuan yang bukan mahram hukumnya haram sekalipun telah lanjut usia dan tidak lagi mampu melakukan hubungan suami istri, selama ia masih berakal dan bukan dalam keadaan terpaksa. Melihat perempuan diperbolehkan dalam kondisi terpaksa atau kebutuhan seorang laki-laki melihat perempuan yang bukan mahramnya ketika hendak melamar, transaksi jual beli, sewa-menyewa, Pinjam-meminjam, belajar mengajar, pengobatan, persaksian, menolong orang tenggelam dan sejenisnya.

Menurut Wahbah Al-Zuhaily melihat perempuan dalam kebutuhan hendaknya harus dibarengi dengan mahramnya, karena keadaan khalwat (berduaan) dapat dimungkinkan terjerumus pada hal-hal yang dilarang oleh syara', dan dalam keadaan tersebut seluruh tubuh perempuan itu harus tertutup kecuali bagian yang dibutuhkan, karena semuanya itu dalam hukum asalnya adalah haram. Menurutnya berkenalan dengan perempuan yang dilamar hanya diperbolehkan dari dua segi saja. Pertama, dengan mengirim seorang perempuan yang telah dipercaya oleh lakilaki yang melamar untuk melihat perempuan yang hendak dilamar dan ia memberitahukan sifat-sifat perempuan itu kepadanya. Kedua, laki-laki yang hendak melamar melihat sendiri perempuan yang akan di lamar untuk mengetahui kecantikan dan kelembutan kulitnya dengan melihat wajah dan kedua telapak tanganya dan perawakannya, karena wajah menunjukkan kecantikannya, kedua telapak tangan menunjukkan kelembutan kulitnya, dan perawakannya menunjukkan tinggi atau pendeknya tubuh. Pendapat Wahbah ini sama dengan isi kitab yang dijadikan rujukan atau literatur dalam menetukan hukum di atas. ${ }^{10}$

Wahbah Al-Zuhaily juga menekankan isu etis dalam hal pinangan seseorang atas pinangan orang lain, sehingga menurutnya ia membolehkan pinangan atau lamaran dengan memenuhi dua syarat, Pertama perempuan yang tidak diharamkan oleh syariat untuk dinikahi selamanya seperti perempuan yang

\footnotetext{
${ }^{10}$ Muhammad bin Ali as-Syaukani, Nailul Author,
} Darul Fikr juz 6 hal 110 tidak termasuk mahram sendiri atau secara temporal seperti saudara perempuan istri atau istri orang lain. Kedua perempuan tersebut tidak dipinang orang lain. Termasuk pula meminang perempuan di masa iddah diperbolehkan dengan cara ta'ridh (sindiran), akan tetapi meminang perempuan dalam kondisi talak ba'in sugra ulama berbeda pendapat. Wahbah Al-Zuhaily berpendapat haram hukumnya melamar perempuan dalam kondisi talak ba'in sugra karena lelaki tersebut masih ada kesempatan untuk kembali lagi kepada istrinya, sedangkan dalam keadaan talak ba'in kubra ia sependapat dengan jumhur ulama yang memperbolehkan melamar perempuan tersebut karena menurutnya suaminya sudah mencerai istrinya secara sempurna dan tidak akan muncul kedengkian di hati suaminya itu.

Dalam membahas aturan-aturan syariah islamiyah Wahbah Al-Zuhaily menyandarkannya kepada dalil-dalil yang shahih baik al-Qur'an, as-Sunnah ataupun akal yang sehat. Sebagaiman usaha seorang mujtahid tidak dapat dianggap sah jika hasil pemikirannya tidak berlandaskan pada al-Qur'an dan as-Sunnah. Oleh sebab itu menurut beliau mempelajari hukum-hukum fiqh dengan sebatas bersandaran pada definisi atau identifikasi masalah atau berdasarkan kemungkinan-kemungkinan atas sesuatu yang bisa terjadi tidak dapat diterima oleh akal dan tidak pula menenteramkan jiwa. Oleh sebab itu pemikiran Wahbah Al-Zuhaily selalu disertai dengan dalil-dalil hukumnya dengan tujuan agar terlepas dari taklid menuju kedudukan ittiba', selain dari menurutnya dalil-dalil hukum merupakan ruh dari fiqih itu sendiri, sehingga dengan mempelajari dalil-dalil hukum akal bisa menjadi terlatih dan keahlian seorang pakar fiqih dapat terbentuk. ${ }^{11}$

Wahbah juga menekankan metode perbandingan antara pendapat-pendapat empat mazdhab (Hanafiyah, Malikiyah, Syafiiyah, dan Hanabilah) dengan disertai penyimpulan hukum (istinbaath al-ahkam) dari sumbersumber hukum Islam baik yang naqli (alQur'an, as-Sunnah, ijma' dan qiyas) ataupun

\footnotetext{
18

${ }^{11}$ Wahbah Al-Zuhaily, Fiqih Islam wa Adillatuhu, h.
} 
yang aqli. Menurutnya kesimpulan hukum Islam yang hanya diambil dari al-Qur'an saja, ia telah melepaskan Islam dari akar-akarnya, dan baragsiapa membatasi fiqih hanya dengan memahami as-Sunnah saja, maka ia telah mereduksi agama Islam dan melakukan kesalahan. Pemikirannya akan pincang dan tidak dapat merelevansikan pemikirannya dengan zaman sehingga tidak akanmemberikan kemaslahatan kepada manusia.

Selain memaparkan pendapat keempat madzhab, Wahbah juga menjelaskan beberapa pendapat madzhab selain yang keempat madzhab, dan ia merujuk langsung pada kitabkitab utama dalam madzhab tersebut. Karena menurutnya, mengutip pendapat suatu madzhab dari rujukan yang tidak sama madzhabnya akan menyebabkan kesalahan penisbatan, terutama dalam pendapat yang paling unggul (rajih) dalam madzhab tersebut. Metode pemikiran yang seperti ini digunakan oleh Wahbah dalam tujuan untuk menghindari penafsiran yang salah serta fanatisme madzhab yang sempit. Dalam penggunaan al-Hadits sebagai dalil dari masalah yang sedang dikajinya, Wahbah memerhatikan keshahihan hadits tersebut. Oleh sebb itu, hadits yang dijadikan rujukan oleh fuqaha di-tahkrij dan di-tahqiq. Metode sepeti ini ia lakukan untuk mengatahui metode yang benar dalam menggunakan dalil, dan dengan cara tersebut ia dapat memilih pendapat yang dalilnya shahih dan meninggalkan padapat yang dalilnya dhaif.

Pemikiran Wahbah Al-Zuhaily lebih fokus pada sisi praktikal, sehingga dalam penulisan bukunya ia tidak menyinggung masalah yang bersifat rekaan atau khayalan yang tidak mungkin dapat terjadi. Ia juga melakukan analisis dari beberapa argumentasi para ulama dan mengambil kesimpulan dari pendapat yang paling unggul (rajih) menurutnya, terutama jika salah satu dari pendapat ulama tersebut merujuk pada hadits dhaif, atau suatu pendapat itu lebih berpotensi memberikan kemaslahatan bagi masyarakat. Jika ia tidak melakukan pentarjih-an, maka yang diambil adalah pendapat jumhur ulama, karena menurutnya dukungan para ulama terhadap suatu pendapat menjadi alasan yang kuat dalam pen-tarjih-an. Menurut Wahbah, dalam kondisi terpaksa (ad-dharuurah), sangat butuh (al-haajah), tidak mampu (al-ajz) atau ada alasan yang lain (al-udzur), maka taqlid terhadap semua madzhab dibenarkan wakaupun sampai pada tahap talfiq. ${ }^{12}$

Menurutnya mencari rukhshakh (tatabbu' ar-rukhas) tidak dibolehkan dalam tujuan main-main dan keinginan atau ego pribadi, seperti mengambil pendapat yng paling ringan dari beberapa madzhab, sedangkan tidak ada kondisi terpaksa (ad-dharuurah), sangat butuh (al-haajah), tidak mampu (al-ajz) atau ada alasan yang lain (al-udzur). Talfiq juga tidak dibolehkan jika bertentangan dengan keputusan hakim dalam menghilangkan sengketa, begitu pula talfiq tidak boleh jika bertentangan dengan tradisi masyarakat atau bertentangan dengan pendapat yang disepakati bersama atau akan terjerumus dalam perbuatan dosa, seperti menikahi perempuan tanpa wali, mahar dan saksi, dengan alasan mengikuti pendapat madzhab yang memperbolehkan hal tersebut. ${ }^{13}$ Ketentuan ini ditetapkan untuk menghindari dan mencegah terjadinya kecendrungan menjauh dari ketentuan perintah-perintah syariah.

\section{Metode Ijtihad Wahbah Al-Zuhaily}

Dalam melakukan ijtihad, Wahbah AlZuhaily terlebih dahulu melakukan kajian terhadap nash-nash yang terdapat dalam al-qur'an dengan menggunakan pendekatan disiplin ilmu yang berhubungan seperti ilmu bahasa dengan memperhatikan katakata mujmal, musytarak, atau lafazh yang diragukan termasuk lafazh yang 'amm atau khashsh, haqiqah atau majaz, haqiqah atau 'urf, muthlaq atau muqayyad dll, jika ia menemukan nash yang jelas mengenai masalah yang dikajinya, maka ia berpegang teguh pada nash tersebut dan menghukumi masalah yang sedang dikajinya dengan ketentuan yang ada dalam nash-nash itu. Sedangkan apabila

\footnotetext{
${ }^{12}$ Wahbah Al-Zuhaily, Fiqih Islam wa Adillatuhu, h. 20 21
} 
ia tidak menemukannya dalam Kitabullah, maka ia mencari dalam sunnah Rasul yang berupa perkataan (Qauliyah), contohnya sabda Nabi SAW :

"Orang mukmin dengan orang mukmin lainnya bagaikan sebuah bangunan, yang satu sama lain saling menguatkan." (HR. Muslim).

Apabila ia tidak menemukannya dalam hadits qauliyah, ia mencarinya dalam hadits yang berupa perbuatan (amaliyah) yang mencakup perilaku Nabi SAW, seperti tata cara shalat, puasa, haji, dan sebagainya. Berikut contoh haditsnya, Seorang sahabat berkata:

"Nabi SAW menyamakan (meluruskan) saf-saf kami ketika kami melakukan shalat. Apabila saf-saf kami telah lurus, barulah Nabi SAW bertakbir." (HR. Muslim).

Jika ia tidak menemukannya dalam keduanya maka ia mengambil hadits yang berupa penetapan (taqririyah) atau penilaian Nabi SAW terhadap apa yang diucapkan atau dilakukan para sahabat yang perkataan atau perbuatan mereka tersebut diakui dan dibenarkan oleh Nabi SAW. Contohnya hadits berikut, seorang sahabat berkata;

"Kami (Para sahabat) melakukan shalat dua rakaat sesudah terbenam matahari (sebelum shalat maghrib), Rasulullah SAW terdiam ketika melihat apa yang kami lakukan, beliau tidak menyuruh juga tidak melarang kami" (HR. Muslim).

Apabila ia menemukan dalam hadits tersebut tentang hukum dari masalah yang sedang dikajinya maka ia menggunakan hadits amaliyah atau taqririyah itu sebagai dalil atau sumber hukum.

Jika dari kedua sumber tersebut ia tidak menemukan kepastian hukum dari masalah yang sedang dikaji, Wahbah Al-Zuhaily kemudian memperhatikan beberapa pendapatpandapat ulama dengan memperhatikan hadits yang dijadikan dalil oleh para ulama tersebut antara shahih dan dhoifnya dengan cara ia melakukan pen-takhrij-tan dan pentahqiq-kan agar hadits-hadits tersebut dapat diketahui shahih dan dhoifnya sehingga bisa memilih pendapat yang bersandar pada hadits shahih. ${ }^{14}$ Kemudian Wahbah melakukan tarjih terhadap pendapat yang mengacu pada sandaran dalil yang shahih, atau jika hadits yang digunakan sebagai dalil oleh para ulama tersebut mempunyai kekuatan yang sama dalam derajat hadits, maka Wahbah Al-Zuhaily lebih memilih pendapat yang mempunyai potensi lebih untuk menimbulkan kemaslahatan dan menolak kerusakan. Jika Wahbahtidak melakukan tarjih terhadap bebepara pendapat ulama, ia lebih mengutamakan untuk mengamalakan pendapat jumhur ulama, alasannya dukungan para ulama terhadap satu pendapat dapat dijadikan alasan kuat dalam pen-tarjih-an.

Jika tidak menemukannya dalam beberapa pendapat ulama, ia melakukan qiyas dengan ilhaq atau mempertemukan masalah yang sedang dikajinya dengan masalah yang sudah mempunyai ketentuan hukum dari sumbernya yang mempunyai kesamaan illat, kemudian ia menghukumi masalah yang dikajinya dengan hukum yang sama dengan masalah yang sudah mempunyai ketentuan hukum dari sumbernya. Selain dari itu kemudian ia juga menggunakan logika yang sesuai dengan aturan dalam hukum Islam. Demikian cara atau metode ijtihad yang ia lakukan, adakalanya merujuk kepada makna lahiriyah nash, jika memang nash tersebut sesuai dengan realitas masalah yang sedang dikajinya. Adakalanya ia juga menganalogikan masalah tersebut dari nash-nash yaitu qiyas, atau dengan menimbang realitas maslahah yang dihadapinya dengan menggunakan kaidah-kaidah umum yang digali dari dalil-dalil al-Qur' an dan as-Sunnah seperti istihsan, maslahah mursalah, urf, sadd adz-Dzari'ah dan yang lainnya. ${ }^{15}$

Adapun cara istihsan yang digunakan Wahbah Al-Zuhailya yaitu dengan Mengunggulkan (memakai) qiyas khafi dan meninggalkan qiyas jali karena ada petunjuk untuk itu, dimana istihsan ini disebut dengan istihsan qiyasi. Atau dengan cara Pengecualian masalah juz'iyah dari Ashal yang bersifat Kully atau dari kaidahkaidah yang berlaku umum karena ada dalil $19{ }^{14}$ Wahbah Al-Zuhaily, Fiqih Islam wa Adillatuhu, h.
119 
(petunjuk) khusus yang mengharuskan hal tersebut yang disebut dengan istihsan istisna' ${ }^{\prime} .^{16}$ sedangkan metode Wahbah Al-Zuhaily di dalam maslahah mursalah yaitu dengan menentukan sebuah hukum yang dapat memperbaiki peraturan syariat atau tujuan syariat (maqasyit al-syariat) yang sebelumnya tidak ada ketentuan dalil dalam syariat, sehingga dapat terwujud menarik kebaikan (jalbu al-mashalih) dan menolak kerusakan (dar'u al-mafasid). ${ }^{17}$ Sedangkan dalam urf yang digunakan oleh Wahbah Al-Zuhaily adalah urf yang sudah berlaku secara umum dari masa sahabat dan sesudahnya yang tidak bertentangan dengan nash syara' dan kaidah-kaidah dasar. ${ }^{18}$ Adapun sadd az-Dzari'ah yang digunakan Wahabah Zuhaili yaitu untuk menentukan apakah suatu perbuatan dilarang atau tidak, karena ia bisa menjadi sarana (adz-dzariah) terjadinya suatu perbuatan lain yang dilarang.

\section{Pengertian Al-Ahkam Al-Usrah}

al-Ahkam al-Usroh adalah hukum atau peraturan-peraturan yang yang terkait dengan hubungan manusia dan keluarganya, yang dimulai dengan ikatan perkawinan dan di akhiri dengan harta warisan atau tirkat. Hukum-hukum tersebut mencakup beberapa aspek berikut : (1) Hukum kekeluargaan, kepemimpinan dalam keluarga dan wasiat terhadap anak kecil. (2) Hukum perkawinan mulai dari ketenteuan melamar, menikah, hakhak suami istri dari mahar dan nafakah, hakhak anak dari anak kandung dan anak susuan, lepasnya tali perkawinan yang diinginkan oleh suami seperti talak, dan khulu', atau perceraian karena ada unsur main-main atau tidak adanya nafakah dari suami. (3) Hukum harta keluarga dalam warisan, wasiat, wakaf dan yang harta lainnya yang disandarkan atas kematian. ${ }^{19}$

${ }^{16}$ Wahbah Az-Zuhaily. Usulul Figh Al-Islamy. Dimasq Syria. Darul Fikri. Cet-2 tahun 2001. Juz II, h. 739

${ }^{17}$ Wahbah Az-Zuhaily. Usulul Figh Al-Islamy. Dimasq Syria. Darul Fikri. Cet-2 tahun 2001. Juz II, h. 757

${ }^{18}$ Wahbah Az-Zuhaily. Usulul Figh Al-Islamy. Dimasq Syria. Darul Fikri. Cet-2 tahun 2001. Juz II, h. 831

${ }^{19}$ Wahbah al-Zuhaili "Figh al-Islami wa Adillatuh"
Pengertian al-Ahkam al-Usrah menurut terminologi yaitu Hukum Keluarga yang diartikan sebagai keseluruhan ketentuan mengenai hukum yang bersangkutan dengan kekeluargaan sedarah (seketurunan) dan kekeluargaan karena perkawinan. Kekeluargaan sedarah yaitu pertalian keluarga yang terdapat antara beberapa orang yang mempunyai keluhuran yang sama. Kekeluargaan karena perkawinan adalah pertalian keluarga yang terdapat karena perkawinan antara seorang laki-laki dan perempuan sebagai suami istri. Hukum perkawinan merupakan keseluruhan peraturan yang berhubungan dengan perkawinan. Hukum perkawinan bagian dari Hukum islam dan hukum islam bagian dari ajaran agama islam. Kawin yaitu perjodohan laki-laki dan perempuan menjadi suami istri. ${ }^{20}$

Hukum keluarga adalah bidang hukum yang berurusan dengan isu keluarga dan yang terkait dengan: ${ }^{21}$ (1) Perkawinan (2) masalah yang timbul di seluruh pernikahan, termasuk penyalahgunaan pasangan, legitimasi, adopsi, penganiayaan anak, dan penculikan anak. (3) pemutusan hubungan dan hal-hal tambahan termasuk perceraian, pembatalan, dan perintah tanggung jawab orang tua (di Amerika Serikat, perwalian anak dan kunjungan, tunjangan anak dan tunjangan penghargaan).

Menurut Abdur-Rahman Al-Jazairi, kata nikah (kawin) dapat di dekati dari tiga aspek pengertian (makna), yakni maknalughawi (etimologi), makna ushuli (syar'i), dan makna figh (hukum).Definisi nikah yang dinyatakan oleh para Ulama'. Menurut ulama Hanafiah, "nikah adalah akad yangmemberi faedah (mengakibatkan) kepemilikan untuk bersenang-senang secarasadar (sengaja) bagi seorang pria dengan seorang wanita, terutama gunamendapatkan kenikmatan biologis". Menurut sebagian mazhab Maliki, nikah adalah sebuah ungkapan atau titel bagi suatu akad

\footnotetext{
juz 9 darul fikr Damsyiq 2006, h. 6487

${ }^{20} \mathrm{http}$ //riana.tblog.com/post/ tanggal 17 oktober 2012.

${ }^{21} \mathrm{http}: / /$ id.shvoong.com/law-and-politics/familylaw/2289622-pengertian-hukum keluarga. tanggal 17 oktober 2012.
} 
yang dilaksanakan dan dimaksudkan untuk meraih kenikmatan (seksual) semata-mata". MazhabSyafi'iyah, nikah di rumuskan dengan "akad yang menjamin kepemilikan(untuk) bersetubuh dengan menggunakan redaksi (lafal) "inkah atau tazwaj; atau turunan (makna) dari keduanya". Menurut ulama Hanabilah mendefinisikannikah dengan "akad yang dilakukan dengan menggunakan kata inkah atau tazwaj guna mendapatkan kesenangan (bersenang-senang). ${ }^{22}$

Definisi perkawinan dalam Kompilasi Hukum Islam (KHI) adalah pernikahan yaitu akad yang sangat kuat atau mitsaqan ghalizhan untuk mentaati perintah Allo SWT dan melaksanakannya merupakan Ibadah". Al-Qur'an juga menjuluki mitsaqan ghalizhan (ikatan yang kuat). Artinya, pernikahan itu merupakan perjanjian yang kuat, serius antara mempelai laki-laki (Suami) dan mempelai perempuan (Istri). Oleh sebab itu pernikahan yang sudah dilangsungkan harus dipertahankan kelangsungannya.

Pernikahan dalam Islam adalah penyatuan jiwa dan raga dalam sebuahmaghligai rumah tangga, untuk mencapai kebahagiaan dunia akhirat, sertamengharap ridho Allah SWT. Rumahtangga yang ideal yang di harapkan adalah rumah tangga yang dipenuhi oleh cinta kasih, sikap saling menghargai dan menghormati, saling memberi dan menerima, saling belajar dan mengajar. Rumah tangga di sebut ideal bila hubungan dalam keluarga dibangun atas dasar sikap saling menasehati dalam kebenaran, berlomba melaksanakan kebajikan. $^{23}$

\section{Al-Ahkam Al-Usrah dalam Fiqh Islami wa Adillatuhu}

Jenis atau sifat pernikahan syar'i dari segi dilakukan atau tidak, meurut para ahli fiqih tergantung pada kondisi masing-masing orang, dengan rincian hukum sebagai berikut:

Pertama, fardhu: mayoritas ulama fiqih mengatakan bahwa hukum nikah wajib jika seseorang dihawatirkan terjerumus dalam

\footnotetext{
${ }^{22}$ Muhammad Amin Summa, HukumKeluarga Islam di Dunia Islam (Jakarta : PT. Raja GrafindoPersada), hlm. 45

${ }^{23}$ Sholeh Gisymar, Kado Cinta untuk Istri (Yogyakarta: Arina Publishing, 2005), 65
}

perzinahan dan ia mampu untuk memberikan nafkah kepada istrinya berupa mahar, nafkah batin dan hak-hak pernikahan yang lainnya. Hal tersebut diwajibkan untuk menjaga kehormatan dirinya dari perbuatan haram. Menurut Wahbah segala sesuatu yang merupakan sarana untuk kesempurnaan sebuah kewajiban maka ia hukumnya wajib pula. Dalam hal ini Wahbah tidak jauh berbeda pendapatnya dengan pendapat para ulama yang lain.

Kedua, haram: nikah diharamkan jika dalam pernikahan tersebut laki-laki itu dapat menzalimi dan membahayakan istrinya, seperti tidak mampu memenuhi kebutuhan pernikahan atau tidak dapat berbuat adil terhadap istrinya. Akan tetapi menurut Wahbah jika terjadi benturan antara hal yang mewjibkan menikah dan yang mengharamkannya, seperti ia yakin akan terjerumus pada perzinahan jika tidak menikah dan ia juga yakin akan melakukan kezaliman pada istrinya jika ia menikah, maka menurutnya dalam kondisi seperti ini pernikahan diharamkan baginya. Karena karena sesuatu yang haram dan halal bercampur maka yang dimenangkan adalah yang haram. Dalam pendapat ini Wahbah lebih condong pada pendapat Syafi'i yang lebih memenangkan yang haram jika antara halal dan haram bercampur.

Ketiga, makruh: pernikahan dimakruhkan jika seseorang khawatir terjerumus dalam dosa dan marabahaya. Kehawatiran tersebut belum sampai pada derajat keyakinan jika ia menikah, seperti khawatir tidak mampu memberi nafkah, berbuat jelek pada keluarga dan kehilangan keinginan kepada keluarga. Dalam madzhab Hanafi makruh dibagi dua macam: makruh tahrimi (mendekati haram) dan makruh tanzihi (mendekati halal) sesuai dengan kuat dan lemahnya kekhawatiran. Menurut Syafi'i menikha hukumnya makruh bagi orang yang memiliki kelemahan seperti tua renta, penyakit lama dan kesuahan yang berkepanjangan. Dalam ketentuan hukum ini Wahbah tidak mengungkan argumentasinya atau menguatkan salah satu pendapat madzhab di atas. 


\section{Rukun-rukun Pernikahan}

Rukun pernikahan menurut ulama Hanafiah hanya ijab dan qabul saja. Sedangkan menurut jumhur ulama ada empat, yaitu sighta (ijab dan qabul), istri, suami dan wali. Suami dan wali adalah dua orang yang melakukan akad, sedangkan yang dijadikan akad adalah istimta' (bersenang-senang) yang merupakan tujuan kedua mempelai dalam melangsungkan pernikahan. Sedangkan mahar bukan sesuatu yang menentukan dalam akad, mahar hanya merupakan syarat seperti saksi. Dalam ketentuan rukun-rukun pernikahan Wahbah Al-Zuhaily lebih condong pada pendapat jumhur ulama.

\section{Syarat-syarat pernikahan}

Dalam pelaksanaan pernikahan ada beberapa syarat bagi kedua pihak yang melakukan akad, dan beberapa syarat dalam sighat (ijab qabul). Adapun syarat kedua belah pihak adalah: Pertama, mampu melaksanakan akad, dan syarat tersebut bisa terpenuhi dengan adanya sifat tamyiz. Kedua, mendengar perkataan orang lain, sekalipun secara hukmi saja, seperti cuma tulisan saja kepada seorang perempuan yang tidak ada di tempat yang memberikan pemahaman untuk melakukan pernikahan. Adapun syaratsyarat sighat akad yaitu, Pertama dilakukan dalam satu majlis, jika kedua belah pihak hadir. Menurut Hanafiah majlis bisa berubah dengan berjalan lebih dari dua langkah, baik jalan kaki atau kendaraan. Menurut Wahbah pedoman utama dalam ketentuan satu majlis atau beda majlis adalah adat istiadat, karena tindakan apapun yang dianggap telah berpaling dari akad atau pemisah dalam ijba qabul, maka dapat mengubah status majlis akad dan begitu pula sebaliknya. Dalam hal ini Wahbah lebih menggunakan ketentuan hukum adat istiadat dalam argumentasinya.

\section{Pernikahan yang Batal dan Macam-macamnya}

Menurut ulama Hanafiah pernikahan yang tidak sah adalah pernikahan yang cacat di dalam rukun atau salah satu syarat pelaksanaanya, seperti pernikahan anak kecil yang belum tamyiz, pernikahan dengan mahramnya, pernikahan perempuan yang sudah menikah dengan lakilaki lain, pernikahan muslimah dengan lakilaki nonmuslim. Menurut pandangan Wahbah Al-Zuhaily hukum pernikahan yang batil adalah pernikahan yang tidak mengakibatkan konsekuensi apapun dari pengaruh-pangaruh pernikahan yang sah. Oleh karena itu lelaki tersebut tidak boleh menggaulinya serta tidak pula wajib membayar mahar dan memberi nafkah kepada perempuan tersebut. Demikian pula mereka tidak bisa saling mewarisi dan tidak ada hubungan mushaharah (besanan), beliau menguatkan argumentasinya dengan ketentuan perundang-undangan Syiria pasal 50 bahwa "pernikahan yang batil tidak menghasilakan apapun dari pengaruh-pengaruh pernikahan yang sah, walaupun telah terjadi hubungan intim".

Menurut ulama Syafi'iah pernikahan yang batal adalah pernikahan yang tidak sempurna rukunnya. Sedangkan pernikahan yang fasid (rusak) adalah pernikahan yang tidak sempurna syaratnya dan terdapat cacat setelah terlaksananya akad nikah. Secara umum keduanya sama menurut Syafi'iah, dengan demikian tidak wajib adanya mahar, nafkah dan tidak pula ada hubungan mahram sebab mushaharah, penetapan iddah dan nasab.

Menurut Wahbah Al-Zuhaily terdapat sembilan macam pernikahan yang tidak sah dalam pandangan hukum Islam. ${ }^{24}$ Pendapatnya sama dengan penjelasan imam Syafi'i dalam yang dijadikan salah satu rujukannya dalam kitab al-Muhadzdzab yaitu, Pertama, nikah syighar, seperti perkataan "Aku nikahkan kamu dengan putriku, dengan syarat kamu menikahkanku dengan putrimu". Pernikahan ini tidak sah jika budh'u (vagina) yang dijadikan maharnya, akan tetapi jika mereka tidak menyebut budh'u sebagai mahar dan tidak menyebutnya, maka pernikahannya tetap sah. Kedua, nikah mut'ah yaitu pernikahan dengan batas waktu tertentu. Ketiga, nikah orang yang sedang berihram. Keempat, poliandri

\footnotetext{
${ }^{24} \mathrm{Abu}$ Ishaq Ibrahim bin Ali bin Yusuf al-Fairuz, $\mathrm{Al}$ Muhadzdzab, juz 2, h. 46-47
} 
yaitu dua orang wali menikahkan seorang perempuan dengan dua orang laki-laki yang tidak diketahui secara jelas dari keduanya siapa yang lebih duluan. Kelima, pernikahan perempuan yang sedang iddah dan perempuan yang sedang istibraa' (perempuan yang sedang membersihkan rahim dari pengaruh sperma suami sebelumnya). Keenam, nikahnya perempuan yang ragu dengan kehamilannya sebelum habis masa iddahnya.

Ketujuh, nikahnya muslim dengan perempuan kafir, selain dari ahli kitab. Menurut Wahbah perempuan ahli kitab, jika ia keturunan Israil, maka dihalalkan menikahinya selama keluarga ushulnya tidak beragama Yahudi setelah agama tersebut dihapus. Jika beragama kristen dihalalkan menikahinya, jika diketahui bahwa keluarga ushulnya beragama kristen sebelum dihapus, sekalipun setelah ajarannya dirubah, dengan syarat mereka menjauhi ajaran-ajaran yang dirubah tersebut. Dalil yang dikemukakan Wahbah dalam pendapatnya ini adalah firman Allah SWT yang berbunyi, "(dan dihalalkan mangawini) wanita yang menjaga kehormatan diantara wanita-wanita yang beriman dan wanita-wanita yang menjaga kehormatan di antara orang-orang yang diberi Al Kitab sebelum kamu". Kedelapan, perempuan yang suka pindah-pindah agama. Kesembilan, pernikahan seorang muslimah dengan laki-laki kafir dan pernikahan perempuan murtad.

\section{Kesimpulan}

Wahbah Al-Zuhaily dalam berijtihad bersandar terhadap nash-nash yang terdapat

\section{DAFTAR PUSTAKA}

Arfan Abbas. Geneologi Pluralitas Mazhab dalam Hukum Islam, UIN Malang Pers, 2008.

Abdul, Khalaf Wahhab.Kaidah-Kaidah Hukum Islam, PT Raja Grafindo Persada, Cetakan Keempat, 1994.

Asikin Zainal \& Amiruddin. Pengantar metode penelitian Hukum, Jakarta raja Grafindo Persada, 2006.

Abu Ishaq Ibrahim bin Ali bin Yusuf al-Fairuz, "Al-Muhadzdzab". dalam al-qur'an, kemudian hadits Rasul yang berupa perkataan (Qauliyah), perbuatan (amaliyah) dan berupa penetapan (taqririyah) kemudian pendapat-pandapat ulama dengan memperhatikan hadits yang dijadikan dalil oleh para ulama tersebut antara shahih dan dhoifnya, ia juga melakukan qiyas, istihsan, maslahah mursalah, urf, sadd adz-Dzari'ah dan yang lainnya.

Menurut Wahbah Al-Zuhaily macam-macam pendahuluan pernikahan dalam kitabnya terdapat empat macam, yaitu hukum pernikahan secara syari' at, hukum khutbah pernikahan, pinangan dengan pinangan orang lain, dan melihat perempuan yang telah dipinang sebelum dinikahi. Sedangkan tentang hukum keluarga (al-Ahkam al-usrah) menurut Wahbah Al-Zuhaily bisa sunnah, wajib, mubah, makruh bahkan haram, tergantung konteksnya. Wahbah Al-Zuhaily juga menyebutkan ada sembilan macam pernikahan yang tidak sah dalam pandangan hukum Islam yaitu: ${ }^{25}$ nikah syighar, nikah mut'ah, nikah orang yang sedang berihram, poliandri, pernikahan perempuan yang sedang iddah dan perempuan yang sedang istibraa' (perempuan yang sedang membersihkan rahim dari pengaruh sperma suami sebelumnya), nikahnya perempuan yang ragu dengan kehamilannya sebelum habis masa iddahnya dan nikahnya muslim dengan perempuan kafir, selain dari ahli kitab.

${ }^{25} \mathrm{Abu}$ Ishaq Ibrahim bin Ali bin Yusuf al-Fairuz, $\mathrm{Al}$ Muhadzdzab, juz 2, h. 46-47

Ashofa Burhan. Metode apenelitian Hukum, Jakarta, Rineka Cipta, 2004.

Bungin Burhan. Metodologi Penelitian Kualitatif; Aktualisasi metodologis kearah ragam varian kontemporer, Jakarta, raja Grafindo Persada, 2007.

Cik Bisri Hasan. Pilar-pilar penelitian Hukum Islam dan Pranata Sosial, Raja Grafindo Persada, 2004.

Ensiklopedi Hukum Islam. Jakarta, Ictiar baru 
170 I de Jure, Jurnal Syariah dan Hukum, Volume 4 Nomor 2, Desember 2012, hlm. 160-170

van Hoeve, 2006.

Gisymar Sholeh. Kado Cinta untuk Istri, Yogyakarta : Arina Publishing, 2005.

http://riana.tblog.com/post/ tanggal 17 oktober 2012.

http://id.shvoong.com/law-and-politics/familylaw/2289622-pengertian-hukum keluarga. tanggal 17 oktober 2012.

Kamus besar bahasa Indonesia. 2 Departemen Pendidikan Nasional, Jakarta, Gramedia Pustaka Utama, 008.

Summa, Muhammad Amin. HukumKeluarga Islam di Dunia Islam, Jakarta : PT. Raja
GrafindoPersada, 2005.

Muhammad bin Ali as-Syaukani, "Nailul Author", Darul Fikr juz 6 hal 218

Syarifuddin Amir. Ushul Fiqh, fajar Interpratama Offset jakarta: kencana, 2009.

Ash Shiddieqy Hasby. Falsafah Hukum Islam, Jakarta, Bulan Bintang, 1974.

Zuhaily Wahbah. al-Figh al-Islam wa Adillatuhu, juz 1, Damascus, Dar al-Fikr, 2006.

Zuhaily Wahbah. Usulul Figh Al-Islamy, Dimasq Syria. Darul Fikri. Cet-2 Juz II, 2001. 